\title{
Characterization of the Mandible Atta Laevigata and the Bioinspiration for the Development of a Biomimetic Surgical Clamp
}

\author{
Thays Obando Brito *, Amal Elzubair ${ }^{a}$, Leonardo Sales Araújo ${ }^{a}$, Sergio Alvaro de Souza Camargo ${ }^{a, b}$, \\ Jorge Luiz Pereira Souza ${ }^{c, d}$, Luiz Henrique Almeida ${ }^{a}$ \\ ${ }^{a}$ Instituto Alberto Luiz Coimbra de Pós-Graduação e Pesquisa de Engenharia - COPPE, Programa de \\ Engenharia Metalúrgica e de Materiais - PEMM, Universidade Federal do Rio de Janeiro - UFRJ, Ilha \\ do Fundão, CP 68505, 21941-972, Rio de Janeiro, RJ, Brazil \\ ${ }^{b}$ Nanotechnology Engineering Program, Instituto Alberto Luiz Coimbra de Pós-Graduação e Pesquisa \\ de Engenharia - COPPE, Universidade Federal do Rio de Janeiro, RJ, Brazil \\ 'Instituto Nacional de Pesquisas da Amazônia, Av. André Araújo, 2.936, 69067-375, Manaus, AM, Brazil \\ ${ }^{d}$ Programa de Pós-Graduação em Ciência e Tecnologia para Recursos Amazônicos, Instituto de \\ Ciências Exatas e Tecnologia - ICET, Itacoatiara, Amazonas - Brazil
}

Received: December 30, 2016; Revised: June 19, 2017; Accepted: July 21, 2017

\begin{abstract}
Approximately thousand years ago it was reported the use of mandibles of ants for suture. In this sense, bioinspired components, as absorbable surgical clamps, can be designed. This study is aimed to characterize the mandible of the ant Atta laevigata in order to help the selection of candidate biomaterials for application as surgical clamps. Three pairs of mandibles were used and ten nanoindenations were performed in each pair. The average hardness for the samples in the internal and external regions were $0.36 \pm 0.06 \mathrm{GPa}$ and $0.19 \pm 0.04 \mathrm{GPa}$, respectively and the average elastic modulus for the internal and external regions were $6.16 \pm 0.23 \mathrm{GPa}$ and $2.74 \pm 0.44 \mathrm{GPa}$, respectively. The morphology of the mandible was observed in detail by scanning electron microscopy, as well as Energy-dispersive X-ray spectroscopy. The average roughnesses on the internal and external regions, measured by atomic force microscopy, were $6.73 \pm 0.90 \mathrm{~nm}$ and $11.87 \pm 1.42 \mathrm{~nm}$, respectively. From these results, it was possible to identify biomaterials that mimic the mandible behaviour for surgical clamp.
\end{abstract}

Keywords: Ant Atta laevigata, Characterization, Surgical clamp and Biomaterials.

\section{Introduction}

Since antiquity, a great number of materials have been tested and used for suture of injuries, such as vegetable fibers, tendons, intestines of many animals, horse mane, golden filaments, among others ${ }^{1}$. There are registers of the use of sutures with linen and gold in Ancient Egypt, as well as the use of cat's intestine in Europe, during the Middle Age ${ }^{2}$. Approximately thousand years ago, the use of mandible of ants for the approximation of the edges of an injury has been reported in the medical Indian text Charaka Sanhita ${ }^{3}$ Based on this knowledge, an absorbable surgical clamp (MU9102934-1) has been designed, emulating the mechanics of bite produced by the mandible of the ant Atta laevigata. This clamp proposed aims to simplify the suture for both placing and the removing from the skin, in a less traumatic and efficient condition for the patient. The suture clamp is composed by the handles and approximation systems ${ }^{4}$. The following step is based on the materials selection of candidates to be used in the surgical clamps, keeping in mind that such materials must be biocompatible. For the handles system, the material must present high elasticity, so to be able to join the edges of the wound for the scarring and, for the approximation system of the clamp the material must be mechanically resistant and bio-absorbable. In order to develop the surgical clamp similar to the mandible, it is necessary

*e-mail: thaysdesigner@hotmail.com to select materials based on a detailed characterization of the properties of the ant mandible. Therefore, in this work, mechanical nanoindentation, scanning electron microscope (SEM), energy-dispersive X-ray spectroscopy (EDS) and Atomic Force Microscopy (AFM) were used for the investigation of the mandible, in order to identify and correlate its properties with the possible biomaterials that can be applied in the bioinspired surgical clamp.

\section{Materials}

\subsection{Biological materials}

Biological materials have been widely used in the past and can still applied or emulated today in Medicine. The properties of biological materials drive scientists and engineers to create new materials or to improve the existing ones. In this regard, it is very important to understand the properties of the biological materials as well as the understanding of the zoology and of the behavior of the living systems ${ }^{5,6}$.

The structures and the characteristics of biological materials can be distinguished among them, and their mechanical properties can be correlated with the synthetic materials according to Table $1^{6-15}$.

The biological material of mandibles of insects can be usually correlated with polymers since; in general, they are 
Table 1. Elastic modulus and tensile strength of biological and synthetic materials ${ }^{15}$.

\begin{tabular}{lccc}
\hline Synthetic materials/ Biological Materials & E (MPa) & $\boldsymbol{\sigma}(\mathbf{M P a})$ & Reference \\
\hline 1.Biopolymer & 150.000 & 18 & 7 \\
Cellulose & 1000 & $50-100$ & 8,7 \\
Collagen (along fibers) & 10.000 & 70 & 7 \\
Fibroin & 5000 & 200 & 9 \\
Keratin (wool) & $0.001-20.000$ & $60-200$ & 10,11 \\
Cuticle (insect) & & & $12-14$ \\
2.Biominerals & 83.000 & 60 & 6 \\
Hydroxyapatite (fron enamel) & 200.000 & 250 & 6 \\
Zirconia & 450.000 & 3500 & 15 \\
Silicon Carbide (SiC) & & & 15 \\
3.Biocomposites & $800-14.000$ & $1-100$ & $30-150$ \\
Trabecular bone & $6000-20.000$ & \\
Cortical bone & & \\
\hline
\end{tabular}

composed by waxes, polysaccharides and proteins. Furthermore, as comparison, jaws of animals are twice more rigid than the exoskeleton due to the presence of metals, like zinc, manganese, iron and, in some cases, calcium. The element zinc is the main responsible for the increase of $20 \%$ of the hardness of the natural material ${ }^{16-21}$. The use of mandibles of the ant Atta laevigata in the suture is efficient, because presents form and mechanics able to join the edges of the wound ${ }^{4}$, as well as it is made of a naturally resistant material. This use of mandible of the ant Atta laevigata acting as a suture component is illustrated in Figure 1.

The species Atta laevigata presents a large head, composed by muscular fibers annexed through the apodeme and interconnected with the mandible, allowing strong mandible movements ${ }^{22,23}$. For the functioning of the suture clamp by the mechanism inspired by the ant's mandible, an external compressive stress must be applied to the levers to force its opening and, when open, the approximation system of the surgical clamp is able to penetrate the skin based on elastic forces. Another important characteristic of the approximation system of the proposed surgical clamp is to be able to fall by itself after the healing ${ }^{4}$. Figure 2 shows a scheme of the functioning of the surgical clamp in the suture analogue to the functioning of the natural system.

\subsection{Biomaterials}

The materials used for medical applications can be divided in four categories: metals, polymers, ceramics and composites $^{24}$. However, metals and polymers are the natural candidates of biomaterials for due to their mechanical, chemical and surface properties. Metals are already largely employed for substitution, reinforcement or stabilization of rigid tissues. They present improved mechanical performance, high mechanical and fracture resistance, durability and possibility of surface polishing and abrasion ${ }^{25-28}$. The main groups of biomaterials are the stainless steels, the titanium alloys, commercially pure titanium and cobalt-chrome based alloys ${ }^{25,29}$. Polymers are less demanding regarding the manufacture of varied forms and a relatively large availability of different classes with mechanical and physical

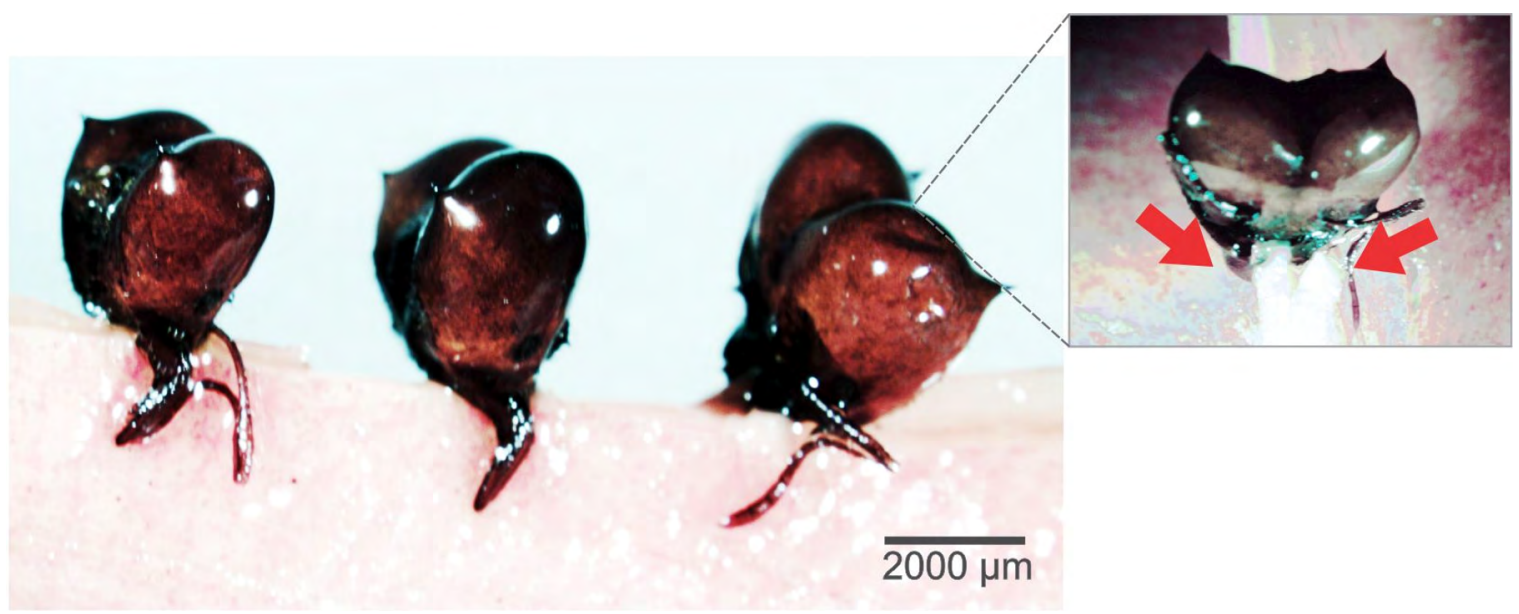

Figure 1. Suture with the mandible of the ant Atta laevigata. 


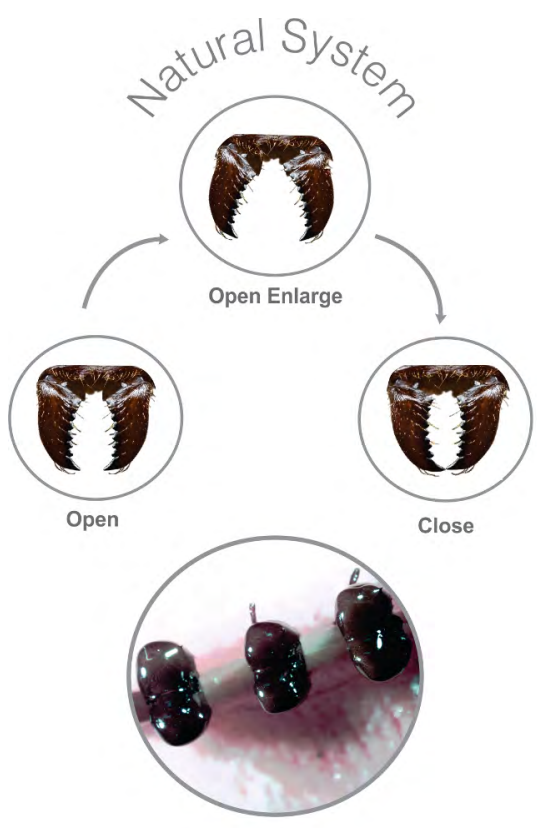

(a)

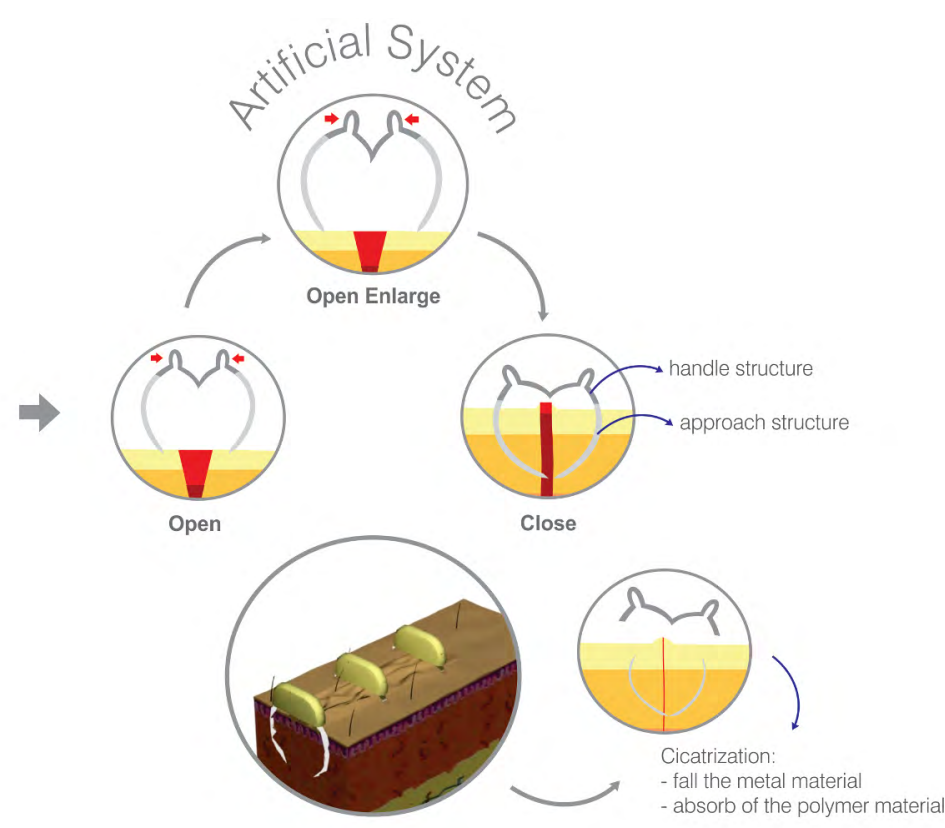

(b)

Figure 2. Mechanism of bite of the ant's mandible Atta laevigata in the suture (a) and functioning of the biomimetic surgical clamp in the suture (b).

properties for specific applications ${ }^{30}$. The main types of synthetic polymers are polylactic acid (PLA), polyglycolic acid (PGA) and the copolymer polylactic-co-glycolic acid $(\mathrm{PLGA})^{31}$. These polymers have been used in biodegradable sutures, absorbable devices for bone fixation and sources for controllable drug release ${ }^{32}$. As more frequently used natural polymers are proteins (collagen, elastin and silk fibroin) and polysaccharides (chitosan, alginate, hyaluronic acid and pectin $)^{33,34}$. The main applications of these biopolymers are in wound treatments and controllable drug release $\mathrm{e}^{35,36}$. It is worth mentioning that the combination between two or more synthetic or natural polymers in the form of complexes or blends, makes it possible to obtain devices with improved chemical, mechanical and biological properties when compared to the isolated polymers ${ }^{33,37,38}$. In general, about the mechanical properties of the different types of biomaterials, it can be noted that the modulus of elasticity of the polymers is generally around $5 \mathrm{GPa}$, while for fibers it can reach $15 \mathrm{GPa}$, for ceramic and metallic materials, the values are approximately 9.0 to $980 \mathrm{GPa}^{39}$.

\section{Materials and Methods}

In this research, three samples of the mandible Atta laevigata were used, with approximately $0.5 \mathrm{~mm}$ in length. Each pair of mandible was sectioned from the ant's head, dried and embedded in epoxy resin, and polished with alcohol and alumina. Instrumented nanoindentation ${ }^{40-42}$ was performed on the surfaces of the samples using an
Agilent G200 nanoindenter, with maximum load of $20 \mathrm{mN}$. Ten indentations were carried out on each of the samples. Scanning Electron Microscopy (SEM - JOEL, JSM - 6460 LV) was used to verify the morphology of the sample. The mandibles were covered with a gold thin film. Through Energy-dispersive X-ray spectroscopy (EDS), the metallic elements of the material were identified. For the examination of the morphological and topographic characteristics on the surface of the mandible, the atomic force microscope (AFM, 1M Plus, JPK Instruments) with non-contact tip, (type NCST-50 and dimensions $27 \times 150 \times 2.8 \mu \mathrm{m}$ ) were used. The arithmetic roughness $(\mathrm{Ra})^{43-45}$ of the sample was determined using the AFM software through a line profile, averaging three profiles for each image of the internal and external regions of the mandible.

\section{Results and Discussion}

The regions in which the indentations were performed on the samples can be identified on the images obtained via optical microscopy coupled to the G200 nanoindenter, as show in Figure 3.

Ten indentations were performed on the inner surface regions, near the denticles, and on the surface of external regions of each sample, in order to verify possible differences in mechanical properties. The results of the nanoindentation on the samples are shown in Figure 4, as load displacement versus displacement into the surface plots. The displacement into surface varies a little in some samples due to irregularities in the surface. 


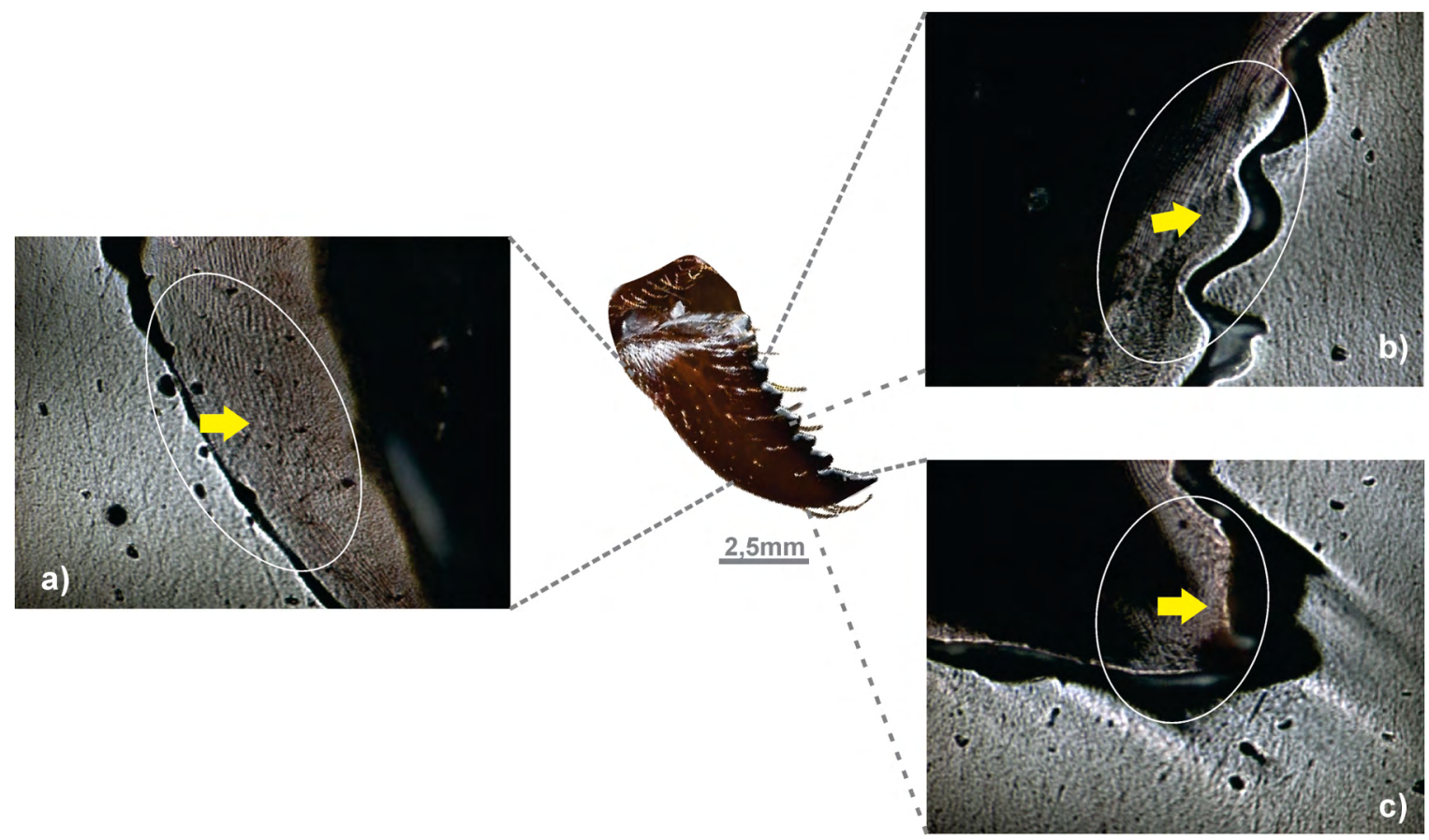

Figure 3. Nanoidentation on the regions of samples: (a) external region, (b, c) internal region of the mandible of the ant Atta laevigata, $10 \mathrm{x}$ magnification.

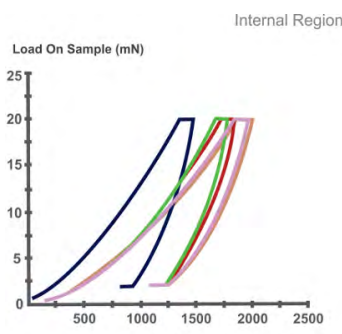

a)

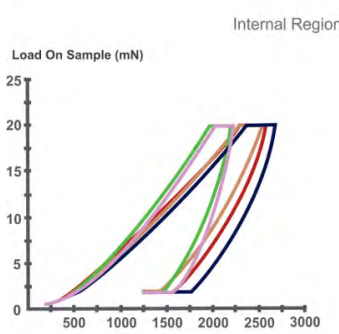

b)

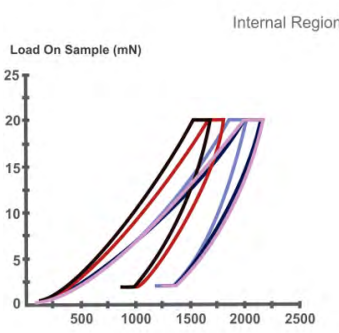

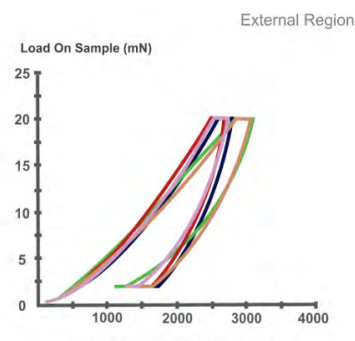

Displacement Into Surface (nm)

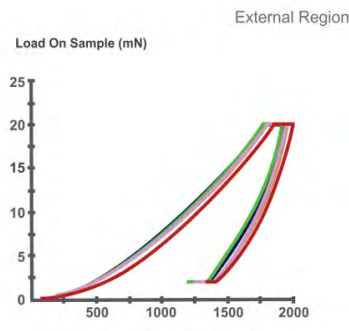

Displacement Into Surface $(\mathrm{nm})$

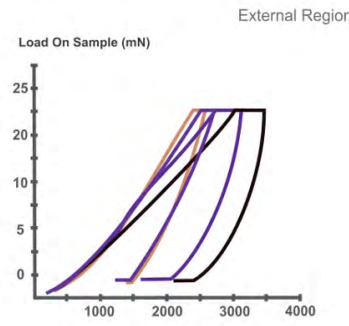

Displacement Into Surface $(\mathrm{nm})$

Figure 4. Load versus displacement into the surface plots on the inner and external surfaces of mandible 1 (a), mandible 2 (b) and mandible 3 (c).

Table 2 shows the comparison of nanoindentation results in the inner and external regions of mandibles 1,2 and 3.

According to Table 2, the hardness and elastic modulus for all samples are higher in the internal region, since this region undergoes higher wear due to the strong movements that the mandible performs to cut different types of materials, indicating greater resistance compared to the external region. The average hardness of the samples in the internal and external regions was $0.36 \pm 0.06 \mathrm{GPa}$ and $0.19 \pm 0.04 \mathrm{GPa}$, respectively. The average elastic modulus in the internal region was $6.16 \pm 0.23 \mathrm{GPa}$ and external of that was 2.74 $\pm 0.44 \mathrm{GPa}$. From these values, it is noteworthy that the material of the ant's mandible presents similarities with some groups of the polymeric materials. Among the absorbable biopolymers for application in the surgical clamp approach system, possible candidates are poly (lactic acid) (PLA), poly (glycolic acid) (PGA) and poly ( $\varepsilon$-caprolactone) (PCL), with respective elastic modulus of 0.3 to $3.5 \mathrm{GPa}, 6$ to $7 \mathrm{GPa}$ and 0.21 to $0.44 \mathrm{Gpa}^{46}$, respectively. PLA and PCL are important candidates because they have been increasingly used in the medical field as they present advantages such as mechanical resistance, ability to combine with other polymer to improve physical-chemical, mechanical and biological properties, as well as non-toxicity, biocompatibility and biodegradability ${ }^{28,47}$. It is also worth to mention that the natural biopolymer fibroin has been used as surgical suture because of its high mechanical resistance and biocompatibility, as well as high resistance to microorganisms ${ }^{48,49}$. Another option of natural biopolymer is chitosan, as it is able to accelerate the healing 
Table 2. Mechanical properties of the samples obtained by nanoindentation.

\begin{tabular}{lcccccc}
\hline & \multicolumn{2}{c}{ MAND 1 } & \multicolumn{2}{c}{ MAND 2 } & \multicolumn{2}{c}{ MAND 3 } \\
\cline { 2 - 7 } & Hardness(GPa) & $\begin{array}{c}\text { Young's } \\
\text { Modulus(GPa) }\end{array}$ & Hardness(GPa) & $\begin{array}{c}\text { Young's } \\
\text { Modulus(GPa) }\end{array}$ & Hardness(GPa) & $\begin{array}{c}\text { Young's } \\
\text { Modulus(GPa) }\end{array}$ \\
\hline Internal Region & $0.45 \pm 0.13$ & $6.00 \pm 1.39$ & $0.32 \pm 0.01$ & $6.41 \pm 1.17$ & $0.31 \pm 0.09$ & $5.09 \pm 0.93$ \\
External Region & $0.17 \pm 0.02$ & $2.28 \pm 0.47$ & $0.22 \pm 0.03$ & $3.54 \pm 1.17$ & $0.18 \pm 0.09$ & $2.40 \pm 0.37$ \\
\hline
\end{tabular}

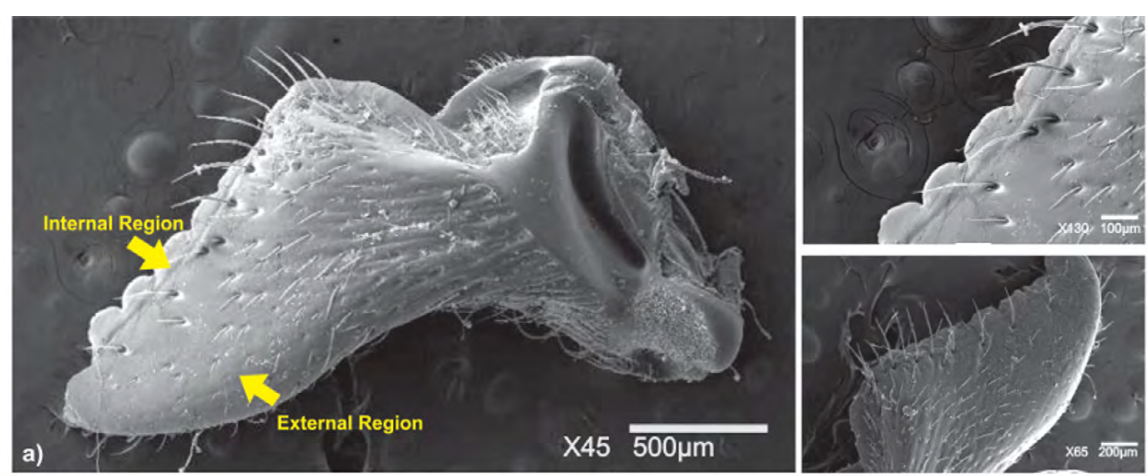

Full scale counts: $200 \quad$ Area $1300 x$

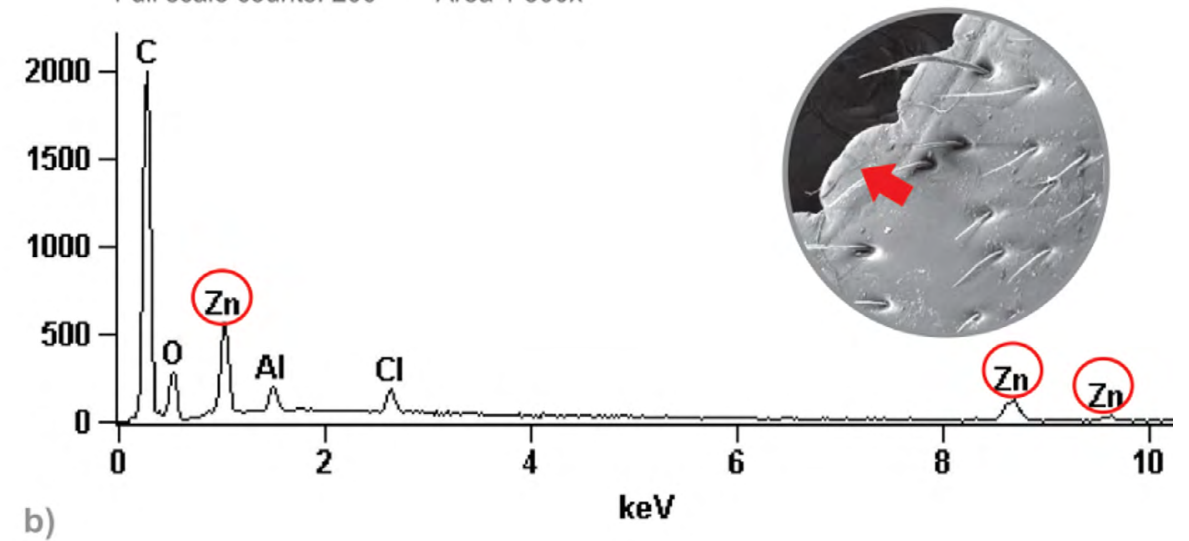

Full scale counts: $200 \quad$ Area $2150 x$

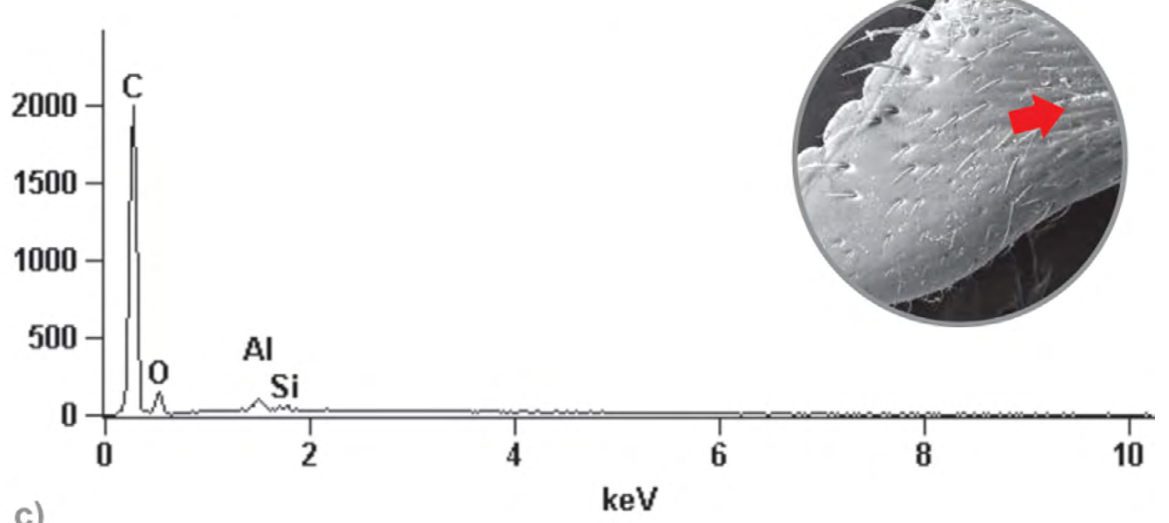

c)

Figure 5. (a) SEM of the mandible Atta laevigata identifying morphological details of the internal and external regions; (b) representative analysis via EDS on the surface of the mandible, identifying metallic elements such as zinc in the internal region, (c) absence of $\mathrm{Zn}$ in the external area. 
of lesions and the synthesis of collagen by the fibroblasts in the initial phase of healing. The combination of two more synthetic or natural polymers forming blends or polymer complexes would be an alternative to the clamp approach system, as it would increase the mechanical strength of the material, facilitating penetration of the surgical clamp approach system into the skin. This happens with the chitosan biopolymer which is combined with other polymeric materials to increase its mechanical strength ${ }^{50,51}$. Another example is the combination of the natural biopolymer, like collagen with the synthetic biopolymer PCL, the objective is also to increase the mechanical properties, as this synthetic polymer exhibits high mechanical resistance ${ }^{52}$. Figure 5 (a) shows the morphology of the mandible of the ant Atta laevigata obtained by SEM, illustrating the basic external morphology of an ant mandible: the external margin; parts of the internal margin including the masticatory margin; basal margin; basal angle; and teeth which has smooth surface. Note the groove extending on the upper right side; similar grooves and pits occur on the mandibles of many ants. Note also the row of setae (hair like structure) along the masticatory border, another common feature of ant mandibles ${ }^{16-21}$.

In addition, EDS analysis in Figure 5 (b) confirmed the presence of metals such as zinc, manganese, aluminum and halogen (chlorine) in ant's mandible samples', principally in the internal region. The analysis of the mandible by EDS indicates the presence of zinc with mass fraction of circa $6.11 \%$. In another region of the mandible, in addition to zinc, $0.46 \%$ of manganese was also identified ${ }^{16-21}$. However, figure 5 (c) shows the absence of zinc in the external region,

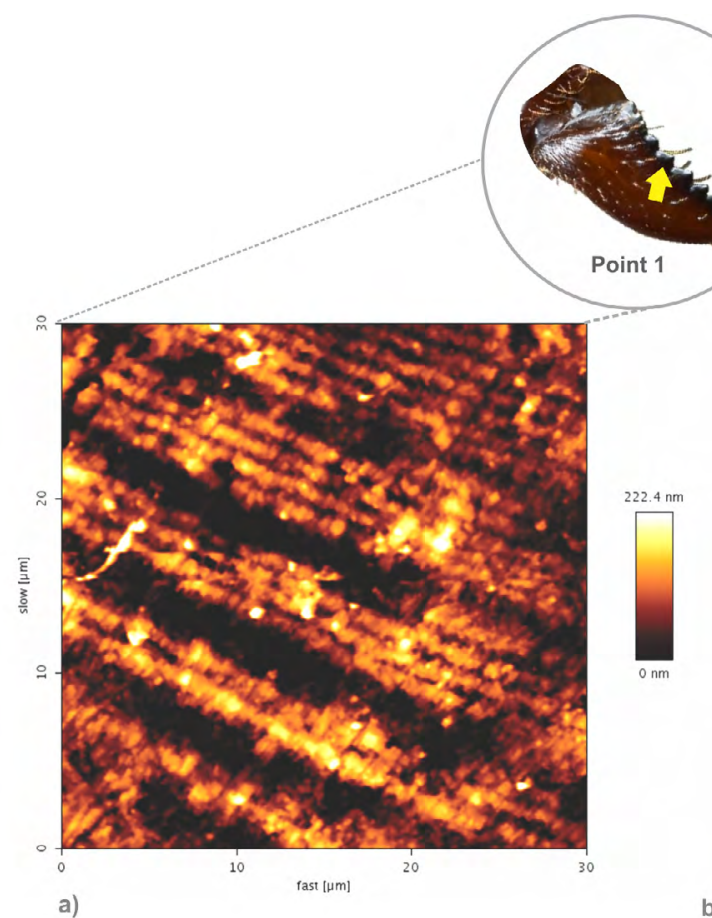

a)
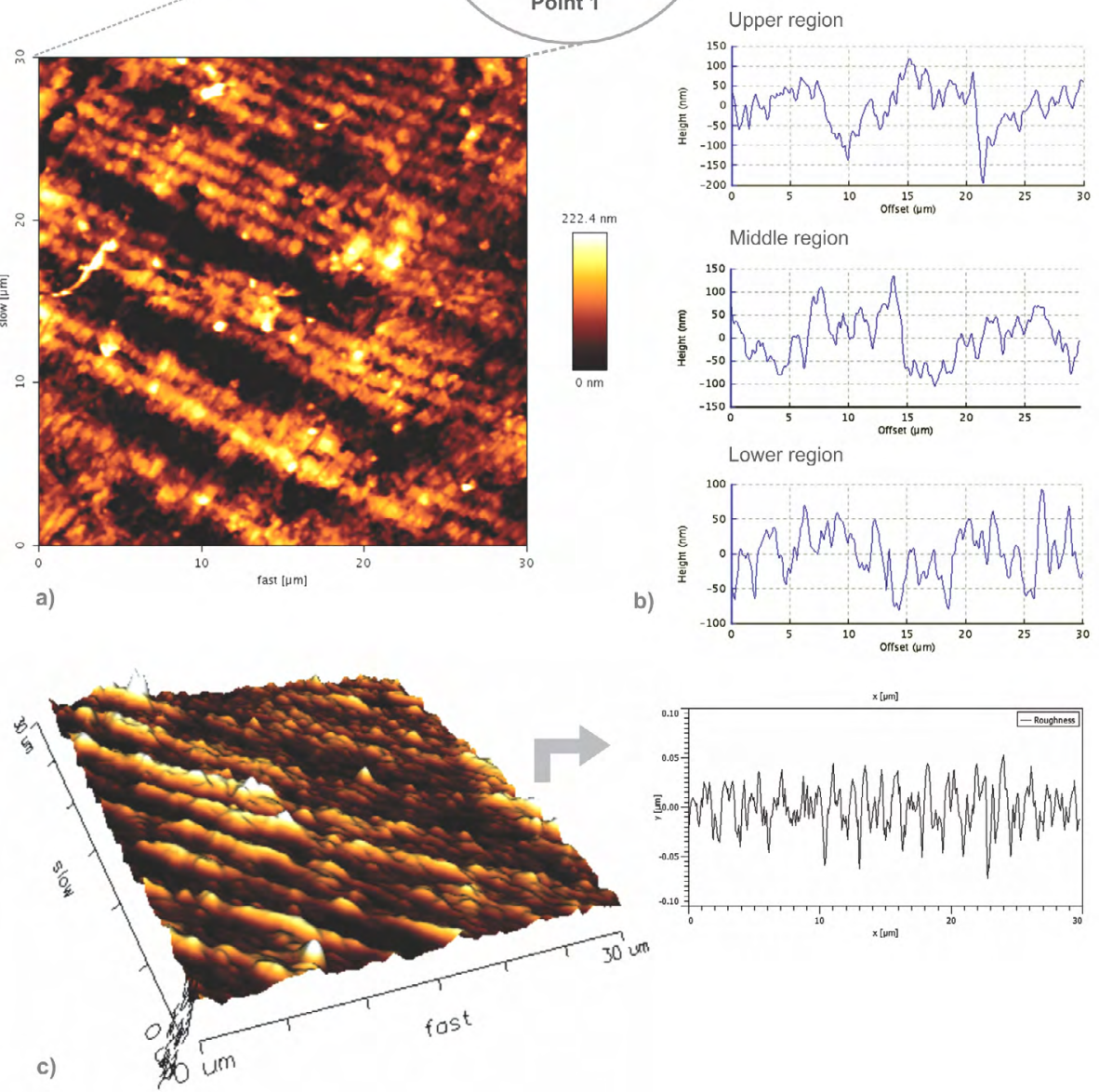

Figure 6. Topography of the internal region on the surface of the mandible of the ant Atta laevigata at different points, $30 \mu \mathrm{m} \times 30 \mu \mathrm{m}$ : surface morphology (a), topographic profile in upper, middle and lower regions (b) and 3D topography (c). 
so these metallic elements may influence the mechanical properties of the mandible such that the higher values of hardness and elastic modulus in the internal region than in the external one can be correlated with the occurrence of zinc and its co-located halogen chlorine., Schofield et al ${ }^{19}$ found that $\mathrm{Zn}$ is incorporated into the mandibular teeth of leaf-cutter ants during early adult life, they show that the hardness of the mandibular teeth increases nearly three-fold as the adults age and that hardness correlates with $\mathrm{Zn}$ content.

The AFM micrographs on the surface of Atta laevigata's mandible are shown in Figures 6 and 7.

The AFM images present topographic similarities in both, the external and internal regions, with a certain vertical inclination of the geometry towards the same direction. The results of roughness parameter $\mathrm{R}_{\mathrm{a}}$ obtained of the internal and external regions of the natural material were $6.73 \pm$ $0.90 \mathrm{~nm}$ and $11.87 \pm 1.42 \mathrm{~nm}$, respectively. These results indicate that in the mandible, the external region presents a higher roughness than the internal region. The morphology (Figura 5 (a)) of both regions can explain the topography or surface roughness. The internal region of the mandible near the denticles is much smoother than the external one which shows irregularities and presence of grooves, pits and rows of setae. Even considering all the activities performed by the mandible, the internal region demonstrated lower roughness (less wear) this may be due to the presence of zinc which enhances its mechanical strength compared to the external region. In biomaterials, surface modification, such as roughness, has been proposed to increase the surface area, adhesion of the interface between the biomaterial and

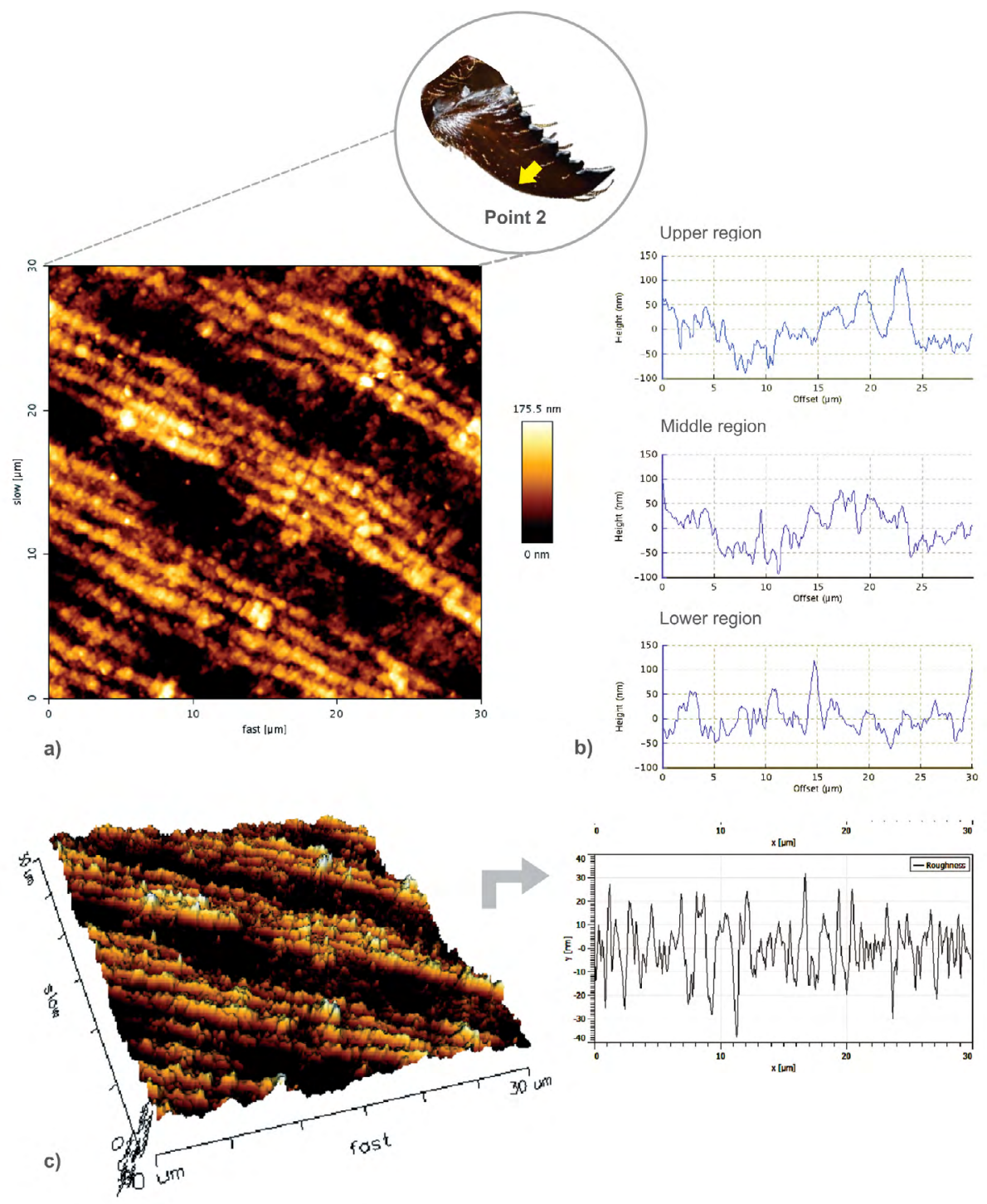

Figure 7. Topography of the external region on the surface of the mandible Atta laevigata, $30 \mu \mathrm{m} \times 30 \mu \mathrm{m}$ : surface morphology (a), topographic profile in upper, middle and lower regions (b) and 3D topography (c). 
the host ${ }^{53}$. Thus, the investigation of $\mathrm{R}_{\mathrm{a}}$ in the mandible will be useful as a parameter for the treatment of surfaces of the biomaterials selected for the surgical clamp, in order to verify the mechanical strength of the biomaterial with roughness similar to the mandible and still the adhesion of drugs to this surface.

\section{Conclusion}

The nanoidentation measurements showed higher hardness and elastic modulus in the internal region of the mandible of the ant Atta laevigata, than the external regions correlated with the presence and absence of zinc, respectively. In addition, metallic elements were found in the internal region of the mandible, such as zinc and manganese justifying the increase of hardness in this region. Morphology and topography details in the internal region, shows smooth denticles, and rougher external region of the mandible. The roughness may serve as a parameter for the surface treatment of the selected polymeric biomaterial to the bioabsorbable surgical clamp. From these results, it was possible to identify biomaterials with potential for application in the surgical clamp approach system, such as PLA, PCL or PGA, individually or in combination with natural polymers, such as chitin, collagen or fibroin, to form blends or polymer complexes. For the clamp handle system, a possible alternative is the use of metallic biomaterials such as stainless steels and titanium alloys.

\section{Acknowledgements}

The authors would like to acknowledge the Foundation for Research Support of the State of Amazonas (FAPEAM), National Council for Scientific and Technological Development (CNPq) for the financial support, and the Laboratory of Characterization of Surfaces of the Federal University of Rio de Janeiro (UFRJ).

\section{References}

1. Makenzie D. The History of Suture. Medical History. 1973;17(2):158-168.

2. Pires ALR, Bierhalz ACK, Moraes AM. Biomaterials: Types, applications and market. Química Nova. 2015;38(7):957-971.

3. Hering F, Gabor S, Rosenberg D. Bases Técnicas e Teóricas de Fios e Suturas. São Paulo: Roca; 1993.

4. Brito TO, Pinheiro CCS, inventors; INPI. Instituto Nacional de Pesquisa da Amazônia (INPI), assignee. Grampo bioabsorvível. Patent BR MU9102934-1. 2012.

5. Chen Q, Pugno NM. Bio-mimetic mechanisms of natural hierarchical materials: A review. Journal of the Mechanical Behavior of Biomedical Materials. 2013; (19):3-33.

6. Chen PY, McKittrick J, Meyers MC. Biological materials: Functional adaptations and bioinspired designs. Progress in Materials Science. 2012;57(8):1492-1704.
7. Meyers MA, Chawla KC. Mechanical Behavior of Materials. $2^{\text {nd }}$ ed. Cambridge: Cambridge University Press; 2008.

8. Fung YC. Biomechanics: Mechanical Properties of Living Tissues. $2^{\text {nd }}$ ed. New York: Springer; 2004.

9. Omenetto FG, Kaplan DL. New Opportunities for an Ancient Material. Science. 2010;329(5991):528-531.

10. Nishino T, Matsui R, Nakame K. Elastic modulus of the crystalline regions of chitin and chitosan. Journal of Polymer Science Part B: Polymer Physics. 1999;37(11):1191-1196.

11. Vincent JFV, Wegst UGK. Design and mechanical properties of insect cuticle. Arthropod Structure \& Development. 2004;33(3):187-199.

12. Osorio AG, Dos Santos LA, Bergmann CP. Evaluation of the mechanical properties and microstructure of hydroxyapatite reinforced with carbon nanotubes. Reviews on Advanced Materials Science. 2011;27:58-63.

13. Marshall GW Jr., Balooch M, Gallagher RR, Gansky SA, Marshall SJ. Mechanical properties of the dentinoenamel junction: AFM studies of nanohardness, elastic modulus, and fracture. Journal of Biomedical Materials Research. 2001;54(1):87-95.

14. Habelitz S, Marshall GW Jr., Balooch M, Marshall SJ. Nanoindentation and storage of teeth. Journal of Biomechanics. 2002;35(7):995-998.

15. Currey JD. Bones: Structure and Mechanics. Princeton: Princeton University Press; 2002.

16. Hillerton JE, Reynolds SE, Vincent JFV. On the Indentation Hardness of Insect Cuticle. Journal of Experimental Biology. 1982;96:45-52.

17. Hillerton JE, Vincent JFV. The Specific Location of Zinc in Insect Mandibles. Journal of Experimental Biology.1982;101:333-336.

18. Quicke DLJ, Wyeth P, Fawke JD, Basibuyuk HH, Vincent JFV. Manganese and zinc in the ovipositors and mandibles of hymenopterous insects. Zoological Journal of the Linnean Society. 1998;124(4):387-396.

19. Schofield RMS, Nesson MH, Richardson KA. Tooth hardness increases with zinc-content in mandibles of young adult leafcutter ants. Die Naturwissenschaften. 2002;89(12):579-583.

20. Cribb BW, Stewart A, Huang H, Truss R, Noller B, Rasch R, et al. Insect mandibles - comparative mechanical properties and links with metal incorporation. Die Naturwissenschaften. 2008;95(1):17-23.

21. Cribb BW, Lin CL, Rintoul L, Rasch R, Hasenpusch J, Huang H. Hardness in arthropod exoskeletons in the absence of transition metals. Acta Biomaterialia. 2010;6(8):3152-3156.

22. Della Lucia TMC. As Formigas Cortadeiras. Viçosa: Sociedade de Investigadores Florestais; 1993.

23. Paul J, Gronenberg W. Optimizing force and velocity: mandible muscle fibre attachments in ants. Journal of Experimental Biology. 1999;202(Pt 7):797-808.

24. Williams DF, ed. Definitions in Biomaterials (Progress in Biomedical Engineering). $4^{\text {th }}$ ed. Amsterdam: Elselvier; 1987.

25. Sumita M, Hanawa T, Teoh SH. Development of nitrogencontaining nickel-free austenitic stainless steels for metallic biomaterials-review. Materials Science and Engineering: $C$. 2004;24(6-8):753-760. 
26. Poinern GEJ, Brundavanam S, Fawcett D. Biomedical Magnesium Alloys: A Review of Material Properties, Surface Modifications and Potential as a Biodegradable Orthopaedic Implant. American Journal of Biomedical Engineering. 2012;2(6):218-240.

27. Hanawa TJ. Materials for metallic stents. Journal of Artificial Organs. 2009;12(2):73-79.

28. Davis JR. Overview of Materials and Their Use in Medical Device. In: Davis JR, ed. Handbook of Materials for Medical Devices. Materials Park: ASM International; 2003.

29. Holzapfel BM, Reichert JC, Schantz JT, Gbureck U, Rackwitz L, Nöth U, et al. How smart do biomaterials need to be? A translational science and clinical point of view. Advanced Drug Delivery Reviews. 2013;65(4):581-603.

30. Wong JY, Bronzino JD, eds. Biomaterials. New York: CRP Press; 2007.

31. Gunatillake PA, Adhikari R. Biodegradable synthetic polymers for tissue engineering. European Cells \& Materials Journal. 2003;5:1-16.

32. Tian H, Tang Z, Zhuang X, Chen X, Jing X. Biodegradable synthetic polymers: Preparation, functionalization and biomedical application. Progress in Polymer Science. 2012;37(2):237-280.

33. Sionkowska A. Current research on the blends of natural and synthetic polymers as new biomaterials: Review. Progress in Polymer Science. 2011;36(9):1254-1276.

34. Sell AS, Wolfe PS, Garg K, McCool JM, Rodriguez IA, Bowlin GL. The Use of Natural Polymers in Tissue Engineering: A Focus on Electrospun Extracellular Matrix Analogues. Polymers. 2010;2(4):522-553.

35. Mogosanu GD, Grumezescu AM. Natural and synthetic polymers for wounds and burns dressing. International Journal of Pharmaceutics. 2014;463(2):127-136.

36. Bellini MZ, Pires ALR, Vasconcelos MO, Moraes AM. Comparison of the properties of compacted and porous lamellar chitosan-xanthan membranes as dressings and scaffolds for the treatment of skin lesions. Journal of Applied Polymer Science. 2012;125(Suppl. 2):E421-E431.

37. Heath DE, Cooper SL. Polymers: Basic Principles. In: Ratner BD, Hoffman AS, Schoen F J, Lemons JE, eds. Biomaterials Science: An Introduction to Materials in Medicine. Oxford: Academic Press; 2013. p. 64-79.

38. Tonhi E, Plepis AMG. Obtenção e Caracterização de Blendas Colágeno-Quitosana. Química Nova. 2002;25(6):943-948.

39. Mano EB. Polímeros como Materiais de Engenharia. São Paulo: Edgard Blücher; 1991.

40. Oliver WC, Pharr GM. Measurement of hardness and elastic modulus by instrumented indentation: Advances in understanding and refinements to methodology. Journal of Materials Research. 2004;19(1):3-20.
41. Whitenack LB, Simkins DC Jr, Motta PJ, Hirai M, Kumar A. Young's modulus and hardness of shark tooth biomaterials. Archives of Oral Biology. 2010;55(3):203-209.

42. Fisher-Cripps AC. Nanoindentation. $2^{\text {nd }}$ ed. New York: Springer; 2004.

43. Associação Brasileira de Normas Técnicas (ABNT). NBR ISO 4287 - Especificações geométricas do produto (GPS) Rugosidade: método do perfil - Termos, definições e parâmetros de rugosidade. Rio de Janeiro: ABNT; 2002.

44. Meyers MA, Lim CT, Li A, Hairul Nizam BR, Tan EPS, Seki $\mathrm{Y}$, et al. The role of organic intertile layer in abalone nacre. Materials Science and Engineering: C. 2009;29(8):2398-2410.

45. Leea GJ, Park KH, Park YG, Park HK. A quantitative AFM analysis of nano-scale surface roughness in various orthodontic brackets. Micron. 2010;41(7):775-782.

46. Van de Velde K, Kieken P. Biopolymers: overview of several properties and consequences on their applications. Polymer Testing. 2002;21(4):433-442.

47. Woodruff MA, Hutmacher DW. The return of a forgotten polymer-Polycaprolactone in the $21^{\text {st }}$ century Progress in Polymer Science. 2010;35(10):1217-1256.

48. Nogueira GM, Rodas ACD, Leite CAP, Giles C, Higa OZ, Polakiewicz B, et al. Preparation and characterization of ethanol-treated silk fibroin dense membranes for biomaterials application using waste silk fibers as raw material. Bioresource Technology. 2010;101(21):8446-8451.

49. Kundu S, ed. Silk Biomaterials for Tissue Engineering and Regenerative Medicine. $1^{\text {st }}$ ed. Cambridge: Woodhead Publishing; 2014.

50. Ávila A, Bierbrauer K, Pucci G, López-González M, Strumia M. Study of optimization of the synthesis and properties of biocomposite films based on grafted chitosan. Journal of Food Engineering. 2012;109(4):752-761.

51. Dallan PRM, Moreira PL, Petinari L, Malmonge SM, Beppu MM, Genari SC, et al. Effects of chitosan solution concentration and incorporation of chitin and glycerol on dense chitosan membrane properties. Journal of Biomedical Materials Research Part B Applied Biomaterials. 2007;80B(2):394-405.

52. Niu G, Criswell T, Sapoznik E, Lee SJ, Soker S. The influence of cross-linking methods on the mechanical and biocompatible properties of vascular scaffold. Journal of Science and Applications: Biomedicine. 2013;1(1);1-7.

53. Klokkevold PR, Nishimura RD, Adachi M, Caputo A. Osseointegration enhanced by chemical etching of the titanium surface. A torque removal study in the rabbit. Clinical Oral Implants Research. 1997;8(6):442-447. 